

results arrived at for each locality compared with the corresponding average of the locality. As regards the precipitation, the amounts in June, July and August, in $\mathrm{mm}$, have been similarly calculated for each locality, and the results compared with the corresponding averages. Further, a calculation has been made of the sum of hours of sunshine in May, June, July and August in each locality; for these values, it was not possible in all instances to obtain measurements precisely from the locality in question; the values of the next available locality were then taken in their place.

The data are as follows:

\begin{tabular}{|c|c|c|c|c|}
\hline & \multicolumn{3}{|c|}{ Sums of temperature } & \\
\hline & 1962 & 1963 & 1964 & Average \\
\hline Piikkiö & 48.1 & 60.9 & 54.0 & 56.2 \\
\hline Pälkäne & 46.4 & 58.4 & 52.3 & 55.0 \\
\hline Laukaa & 44.2 & 54.8 & 49.4 & 51.9 \\
\hline Ylistaro & 44.6 & 54.7 & 49.1 & 53.0 \\
\hline Maaninka & 44.8 & 54.8 & 50.3 & 52.9 \\
\hline \multirow[t]{3}{*}{ Rovaniemi } & 39.0 & 48.3 & 43.6 & 45.8 \\
\hline & \multicolumn{3}{|c|}{ Precipitation } & \\
\hline & 1962 & 1963 & 1964 & Average \\
\hline Piikkiō & 200 & 175 & 144 & 184 \\
\hline Pälkäne & 213 & 158 & 142 & 198 \\
\hline Laukaa & 217 & 154 & 132 & 206 \\
\hline Ylistaro & 184 & 158 & 154 & 195 \\
\hline Maaninka & 186 & 225 & 156 & 188 \\
\hline \multirow[t]{3}{*}{ Rovaniemi } & 166 & 159 & 213 & 196 \\
\hline & \multicolumn{4}{|c|}{ Totals of hours of sunshine } \\
\hline & 1962 & 1963 & 1964 & \\
\hline Piikkiö & 718.4 & 936.5 & 950.5 & \\
\hline Jokioinen & 690.1 & 1004.0 & 954.8 & \\
\hline Jyväskylä & 700.9 & 980.6 & 919.8 & \\
\hline Ylistaro & 764.9 & 1008.5 & 972.9 & \\
\hline Kuopio & 713.4 & 1042.3 & 970.3 & \\
\hline Rovaniemi & 789.8 & 993.1 & 854.4 & \\
\hline
\end{tabular}

The most important difference between the years under study is that the summer of 1963 was warmer than the average, whereas the summer of 1964, and particularly the summer of 1962, were cooler than the average.

In respect of the precipitation, it is not easy to draw general conclusions. In general, the summer of 1964 showed the least precipitation, except in Rovaniemi. The early summer was dry in both 1963 and 1964. In general, the greatest amount of precipitation occurred in August.

As concerns the hours of sunshine, the total was least in 1962 , whereas both 1963 and 1964 were sunny years.

In addition to the above-mentioned totals, a calculation was made of the effective temperature totals corresponding to the periods of growth until picking day for the different samples, taking $+5^{\circ} \mathrm{C}$ as base temperature. Similarly, the corresponding totals of hours of sunshine were calculated. The analytical results were compared with these values. 


\section{Properties investigated}

The following points were studied for characterization of the quality:

1) ascorbic acid (vitamin C)

2) dry matter

3) alcohol-insoluble dry matter

4) pectin, assayed by the carbazole and acid titration methods, and degree of esterification of the pectin

5) $\mathrm{pH}$ and acid content

6) strength of colour

7) formol value

8) aroma number

9) gas chromatographic study of the aroma

10) organoleptic evaluation.

Points $2-7$ are reported in part II of this article, and points $8-10$ in part III.

Furthermore, an evaluation was made of the degree of maturity from the material of the last two years, on the basis of the proportion of unripe berries in

Table 1. Ascorbic acid content of black-currant varieties in the years 1962-1964, and general averages.

Total ascorbic acid

Corrected ascorbic acid

$\begin{array}{lllllll}1962 & 1963 & 1964 & \text { Average } & 1962 & 1963 & 1964\end{array}$

I. Ascorbic acid $\mathrm{mg} / 100 \mathrm{~g}$ fresh weight.

$\begin{array}{lccc}\text { Boskoop } & 250 & - & \\ \text { Roodknop } & 246 & - & - \\ \text { Westwick Choice } & 240 & - & 222 \\ \text { Wellington XXX } & 234 & 221 & 200 \\ \text { Gerby } & 224 & - & 2 \\ \text { Wellington X } & 232 & 170 & \\ \text { Ảström } & - & 194 & 1 \\ \text { Brödtorp } & 152 & 196 & 1 \\ \text { Goliath } & 200 & 106 & \\ \text { Silvergieter } & 194 & 118 & \\ \text { Janslunda } & 160 & 126 & 1 \\ \text { Black of Lepaa } & 89 & 169 & 1\end{array}$

$\begin{array}{rrrrrr}- & 250 & 200 & - & - & 200 \\ - & 246 & 200 & - & - & 200 \\ - & 240 & 214 & - & - & 214 \\ 232 & 229 & 188 & 169 & 210 & 189 \\ 200 & 212 & 178 & - & 154 & 166 \\ 220 & 207 & 186 & 114 & 178 & 159 \\ - & 194 & - & 162 & - & 162 \\ 141 & 163 & 110 & 145 & 103 & 119 \\ 172 & 159 & 146 & 68 & 148 & 121 \\ - & 156 & 158 & 76 & - & 117 \\ 120 & 135 & 124 & 76 & 90 & 97 \\ 122 & 127 & 63 & 141 & 86 & 97\end{array}$

II. Ascorbic acid $\mathrm{mg} / \mathbf{1 0 0} \mathrm{g}$ dry matter.

$\begin{array}{lrrrr}\text { Boskoop } & 922 & - & - & 922 \\ \text { Roodknop } & 1192 & - & - & 1192 \\ \text { Westwick Choice } & 828 & - & - & 828 \\ \text { Wellington XXX } & 811 & 1125 & 1131 & 1022 \\ \text { Gerby } & 1124 & - & 971 & 1048 \\ \text { Wellington X } & 813 & 895 & 898 & 869 \\ \text { Aström } & - & 874 & - & 874 \\ \text { Brödtorp } & 739 & 990 & 736 & 822 \\ \text { Goliath } & 786 & 611 & 811 & 736 \\ \text { Silvergieter } & 867 & 676 & - & 773 \\ \text { Janslunda } & 626 & 668 & 632 & 642 \\ \text { Black of Lepaa } & 496 & 839 & 649 & 661\end{array}$

737
969
738
651
892
652
-
538
574
706
485
352

-
-
-
858
-
600
730
725
392
436
403
701

$\begin{array}{cc}- & 737 \\ - & 969 \\ - & 738 \\ 944 & 818 \\ 748 & 820 \\ 727 & 660 \\ - & 730 \\ 533 & 599 \\ 698 & 555 \\ - & 571 \\ 596 & 495 \\ 457 & 503\end{array}$






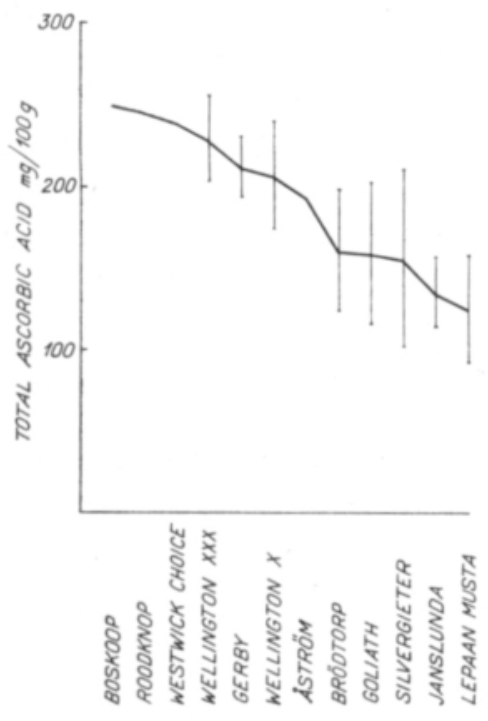

Fig. 3. Total ascorbic acid averages, and standard deviations in black-currant varieties.

For checking purposes, a calculation was made on the basis of the above of the significance of the differences between the varieties of which the number of samples was greatest, viz. Wellington XXX, Brödtorp and Black of Lepaa. The t-test was used for this. Of these varieties, the value of Wellington XXX is highest, Brödtorp is next and Black of Lepaa is lowest. The result is as follows:

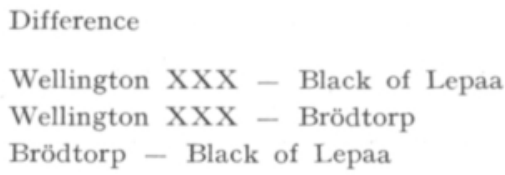

$\begin{array}{cc}\text { Degree of freedom } & \mathrm{P} \\ 19 & 99.9 \% \\ 26 & 99.9 \% \\ 23 & 97.0 \%\end{array}$

Thus the differences between these varieties are very significant, although the difference between Brödtorp and Black of Lepaa is less significant than the other differences considered.

The number of samples was variable; in the best case it was 16 (Brödtorp), and in the worst only one. Consequently the comparison would perhaps be better if the last-mentioned varieties were compared with the values of the other varieties in the same summer. Fig. 4 illustrates the ascorbic acid values of the different years, compared with the averages. Among those varieties for which values referring to at least two years are available (in the diagram, these values are in the right hand corner), the values in 1962 are almost regularly higher than the mean, except as regards the varieties Brödtorp and Black of Lepaa. By contrast, in 1963 the values are ordinarily lower than the mean, the only exception again being Brödtorp and Black of Lepaa. It is thus probable that the real values for the varieties Boskoop, Roodknop and Westwick Choice would be somewhat lower than those obtained, as analysis was carried out in 1962 only; reference to the literature also hints in this direction. It may 


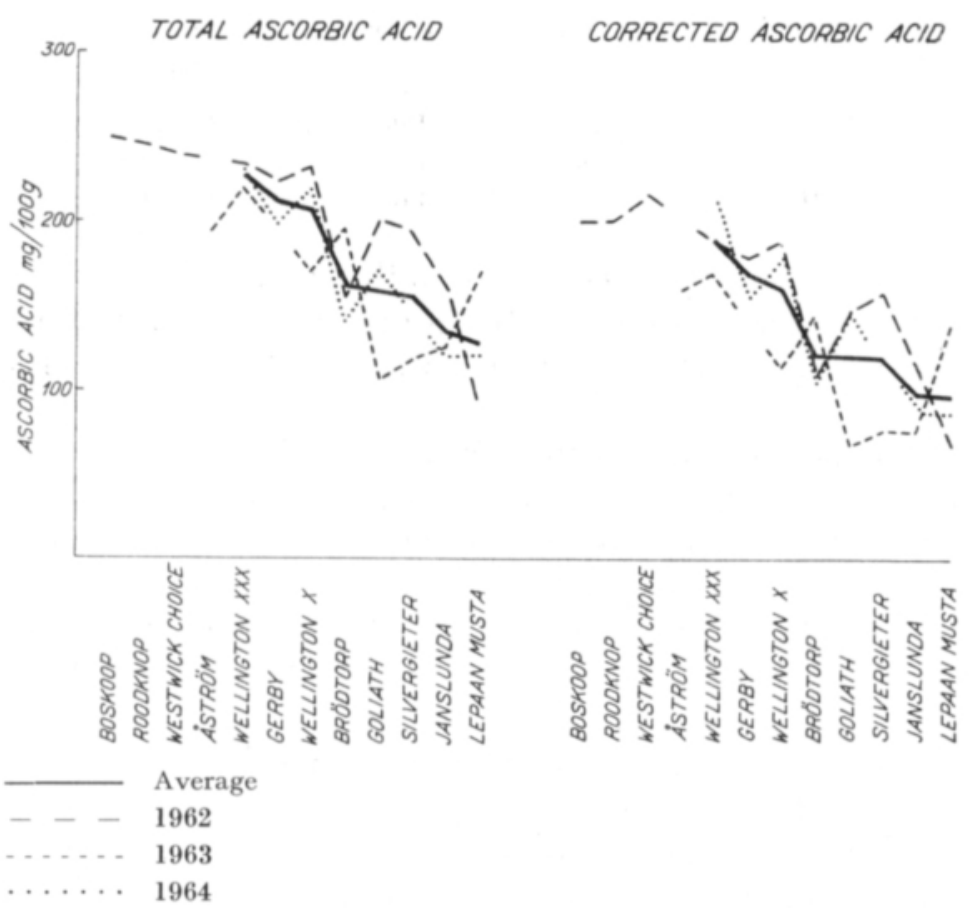

Fig. 4. Comparison of total ascorbic acid content of black-currant varieties in the different years investigated, and the averages.

further be mentioned that in published reports (e.g. 2, 8) Roodknop is a comparatively late, and Westwick Choice a late variety; in the present series, the samples of these varieties were collected early (judged on the basis of totals of temperature until picking) and were rather unripe as a result; this also increased the ascorbic acid content. Similarly, in the variety Åström, which was analysed only in 1963 , it is probable that the real average is higher than the value obtained here. This assumption presupposes that the varieties mentioned, in their relationship to the weather conditions, follow the general trend among the varieties studied, and not the exceptional line of Brödtorp and Black of Lepaa.

In considering the effect of weather conditions on the ascorbic acid content, the factors to be taken into account are the summer temperature, the total of sunshine hours, and the precipitation; figures for these were given at the beginning (pp. 266). As regards the temperature, the summer of 1963 was warmer than average, but the summer of 1964 and especially the summer of 1962 were cooler than average. The ascorbic acid values were highest in the coolest summer, and lowest in the warmest; as was mentioned above, Brödtorp and Black of Lepaa often constituted an exception. However, the degree of maturity may also influence the results, and in most cases this factor is responsible for exceptions to the main rule concerning temperature effect. If a comparison is made of the averages of all varieties for each year, the following data are obtained: 


localities, from Piikkiö to Rovaniemi. If the mean values of ascorbic acid are calculated for all the samples from each locality, Table 3 is obtained; the localities are arranged starting from that most to the south and then northwards.

A rise in the averages is apparent towards the north from Piikkiö as far as Laukaa, but the values of Ylistaro and Maaninka are again lower, and also the Rovaniemi value is somewhat lower than that of Laukaa. For this particular aspect of the study, the average values are somewhat disadvantageous, as the assortment of varieties from the different localities was not the same, and thus the results are influenced by the differences between the varieties. No doubt the comparison would be more reliable if the same variety and year were compared for different localities; for such a comparison, the varieties Brödtorp, Black of Lepaa and Wellington XXX are best suited, as in these cases the number of samples is highest. These values are given in Table 4. Even then, the variability in the ripeness and condition of the berries remains an uncertain factor; by contrast, the assay method was the same in all cases. Furthermore, the ripeness was standardized as much as possible by the discarding of berries which were clearly unripe; however, the separation of possibly overripe berries could not be effected. The degree of overripeness was connected with transport conditions, so that the samples sent by the most rapid means were least changed during transport.

When a comparison is made of the total ascorbic acid values of the same variety, it can be established that as regards Wellington XXX there existed no clearly increasing tendency from south to north in any of the years. In the averages for the 3 years, such an increase seems to have occurred, although the Ylistaro and Maaninka values, where secondary changes took place during transport, constituted exceptions. In Brödtorp, similarly, there is observable no clearly rising tendency towards the north in the series of the different years; the maximum is somewhere in the middle. In 1964, the highest value was at Rovaniemi, but the other values did not follow the order of progression towards the north. In the averages for the 3 years, some kind of a tendency rising towards the north is found, although the Ylistaro and Maaninka values deviate. It is more difficult to draw conclusions with regard to Black of Lepaa, as the series were small, and ripeness and the condition of the berries varied considerably. A rise towards the north was found only in 1963 (158 at Piikkiö, 180 at Laukaa), although this may not be reliable evidence, since in general the values in Laukaa were particularly high.

On the basis of corrected ascorbic acid, a rather similar picture is arrived at. In Wellington XXX and Brödtorp, some increase towards the north is observable in the averages for the 3 years, but the correlation is not perfect: in Wellington XXX, the Ylistaro and Maaninka values were exceptionally low, in the same way as the total ascorbic acid, and in Brödtorp the value of Laukaa was higher than the rest of the series (this sample was found to be somewhat unripe). The tendency to increase towards the north is less evident for each individual year; thus for example the values of Wellington XXX in 1964, from Piikkiö to Rovaniemi, were very much on the same level, except for the samples from Ylistaro and Maaninka which suffered under transport.

In conclusion, these results indicate that the effect of the degree of north latitude 
in increasing the ascorbic acid content seems uncertain. It might be that this effect, when it does apparently occur, is primarily a consequence of the low summer temperature and the degree of maturity connected with it, rather than of the length of day. HÅRDH $(9,10)$ has also established the fact that a cool summer increases the amount of ascorbic acid. Further, JoycE (11) obtained corresponding results with black-currant in Scotland: on comparison of the ascorbic acid content of different varieties at two localities, he regularly found higher values at the cooler locality. Although FERNQUisT \& Nilsson (6) found a difference in ascorbic acid content by reason of the length of day, when a comparison was made between 8 hours and more than 12 hours (the former value was about $40 \%$ lower), it should be mentioned that in all the localities studied here there prevailed long-day conditions, as the length of day, even in the southern part of Finland, averages 17-18 hours during the summer. The light thus probably was not in reality a minimum factor.

If the concept of "northernness», and its effect on plants is considered in general, it can be established that this concept includes several different factors with complicated mutual interrelationships. It is well known that the temperature falls towards the north (cf. 18, mean temperatures in July; the values of the years studied were given on pp. 266), and therefore the growth period of the plant is shortened (cf. 16). The length of the day, i.e. the total of daylight hours, increases towards the north, so that in July, in southern Finland, it is approximately 17-18 hours, and in Lapland it attains a length of even 24 hours. However, the amount of total radiation per unit area is somewhat decreased from south to north; thus during the period May to September, the amount of radiation is about $58 \mathrm{kcal} / \mathrm{cm}^{2}$ in Piikkiö, whereas in Rovaniemi the corresponding figure is about $52 \mathrm{kcal} / \mathrm{cm}^{2}$ (18; cf. also 16). The light exercises two different effects: it is essential for the assimilation, but on the other hand also influences the rhythm of growth. The so-called "short-day" and "long-day" plants are adapted to different lengths of day, and if the length of the lighted period is unsuitable, the reproductive phase is inhibited or delayed (cf. e.g. $13,14,15)$. As regards the black-currant, it seems reasonable to assume that the varieties grown in Finland are principally long-day plants, as they flower and thrive under long-day conditions; the results of FERnQuisT \& NiLSSON (6) mentioned above provide an indication of this. As was mentioned above, in Finland the conditions are of long-day nature from the south to the north, so that a typical shortday effect, such as that found by FERNQUiST \& NILSSON, in unobtainable without special dark arrangements. Reference might also be made to the statement of Pohjakallio (15) that the day-length effect is most marked in the vegetative phase before flowering, whereas in the subsequent phase the effect of temperature is of decisive importance. Assimilation, again, depends upon the amount of total radiation, which diminishes somewhat towards the north. PoHJakallio (16) assumes that the longer day in the far north is in broad outline sufficient to compensate for the inferiority of the amount of total radiation, and thus in favourable years the rate of growth and the crop in the north is comparable with those obtained in southern Finland. However, in the north the low temperature, i.e. the shortness of the growth season, is the most limiting factor. Furthermore, the latitude determines the maximum amount of total radiation which is possible. In the values for Piikkiö and Rova- 

The comparison shows that as regards the varieties Boskoop, Roodknop and Westwick Choice, the present results are higher than those presented in the literature, which is related to the fact that in general the values for the year in question are higher than average. However, it may be mentioned that Groven (8) and Joyce (11) have obtained rather high values for Westwick Choice. Similarly the value for Boskoop in Tasmania is even higher than the present result. There are two types of this variety, which may cause variations.

For Wellington XXX, the present results somewhat exceed the values of CHARLEY, but fit in well with BaUmann's results; the values arrived at by HÅrdH are lowest of all. As far as Brödtorp is concerned, the present results again agree with those of BaUmann, but are higher than the values of HÅrdH, Groven and LaRsSon. Tressler \& JosLyn give for Brödtorp 120-140 mg/100 $\mathrm{g}$ for Finnish material, and $130 \mathrm{mg} / 100 \mathrm{~g}$ for that of Scotland. In the case of Black of Lepaa, the values of HÅRDH are somewhat higher than the present results, although they still remain between the limits of variation obtained here. In the foreign series, this variety is absent, as is the variety Gerby. In Larssons series, Åström and Janslunda gave low values in northern Sweden.

The results in respect of Wellington $\mathrm{X}$ obtained here are very clearly higher than the values of BAUMANN. It is difficult to know whether the variety in question was exactly the same in both cases, or if the difference could be attributed to any other reason. However, in LARSSON's series the value for this variety is almost as high as that found here. Similarly, in the case of Goliath the present results are higher than those of Baumann. For the values of 1954-56, Baumann specifies that the variety Goliath was mechte Typen; according to BAUMANN this variety is not to be recommended for culture because of the low ascorbic acid content. Furthermore, the value for the material from Tasmania, and that from Scotland according to JoYcE, correspond approximately to the present results; the Canadian value is even higher. In contrast, the value for Silvergieter in the present results is lower than those of Charley, Joyce and Groven, whereas the values of BAUMANN, while evidencing rather great variation, are approximately of the same order as the present results; the results obtained by HÅRDH and LARSSON are lower. With respect to the methods applied, it may be mentioned that HÅrDH used the same one as that in the present study, whereas the method of CHARLEY differed. In most cases, the method used is not reported.

As a whole, the present results correspond rather well to the information found in literature, although the variation is rather great, and deviations are to be noted in both directions.

The question of the effect of the latitude might still be considered in the light of the table presented. It appears, however, impossible to answer it unambiguously. Even the method of assay itself might have exercised too great an influence, as it was not the same in all cases. However, it may be said that the value of home-grown Silvergieter is lower than that of foreign material, whereas the situation is the opposite for Wellington X and Goliath; in other varieties, the differences are less marked. 


\section{$S u m m$ ary}

A comparative study has been made with a view to clarification of the quality properties of some home-grown black-currant varieties. Twelve varieties were examined; samples were obtained from 6 different localities, of which the southernmost was Piikkiö, and the northernmost Rovaniemi, over a period of three years. The analytical results were compared with the totals of heat, the totals of hours of sunshine, and the precipitaition during the years concerned.

Ascorbic acid, one of the most important criteria of quality, was assayed by application of the method of Robinson \& Stotz, slightly modified. On the basis of the results obtained, mutual comparison of the varieties studied is possible along with consideration of the possible effects of weather conditions and the degree of north latitude of the place of growth. It is well known that the ascorbic acid content is dependent upon the variety. Accordingly, the following diminishing sequence was found in the ascorbic acid content of the varieties studied: Boskoop, Roodknop, Westwick Choice, Wellington XXX, Gerby, Wellington X, Åström, Brödtorp, Goliath, Silvergieter, Janslunda and Black of Lepaa. In this series, the amount of ascorbic acid fell from 250 to $127 \mathrm{mg} / 100 \mathrm{~g}$; considerable variations occurred in each variety.

As for weather conditions, the summer temperature showed the greatest effect; in general, low temperature increased the amount of ascorbic acid. However, Brödtorp and Black of Lepaa often formed an exception. The number of hours of sunshine produced a similar effect, but to a lesser degree; by contrast, precipitation evinced no clear-cut effect. The degree of north latitude of the locality also seems to exert some effect, probably mainly because a latitude further north means a lowering of the temperature, and consequent retardation of the ripening, which again causes higher ascorbic acid values.

Comparison with published reports shows that in principle the present results are in line with those presented earlier. The differences might be attributable to different methods of assay, or variability in the varieties concerned. The northern latitude of the place of growth and the degree of maturity may be of importance.

My thanks are due to the Department of Horticulture, and to the experimental stations which provided the material.

\section{REFERENCES}

(1) Baumann, J. 1959. Experiments in black currant growing. Flüss. Obst 26, 9: 10-15. (Ref. TressLER \& JOSLYN, p. 456).

(2) - 1960. Die schwarze Johannisbeere 1960. Ibid. 27: 5-19.

(3) - -1961 . Schwarzer Johannisbeer, ein Kleinod unter den Süssmosten. Ibid. 29, 5, 4-5.

(4) - 1962. Aspetti della utilizzazione del ribes nero. Riv. Ortoflorofrutticolt. Ital. Anno 86, Vol. XLV, N. 6: 688-699.

(5) Евкама, J. 1946. Kolorimetrisestä C-vitamiinin määrityksestä 2,6-diklorfenoli-indofenolilla. S. kemistilehti 19: 21-25. 
(6) Ferngvist, I. \& Nilsson, F. 1961. C-vitaminet - funktion och förekomst speciellt hos frukt och bär. Frukt i år 1961: $81-86$.

(7) Genevois, L. 1960. La répartition des vitamines chez les végétaux I. L'acide ascorbique. Ann. nutrition et aliment. XIV No 3 Revue $1-52$.

(8) Groven, I. 1962. Sortsforsøg med solbaer. Tidskr. for Planteavl 65: 411-434.

(9) HÅRDh, J. E. 1964. Mustaherukan C-vitamiinipitoisuuteen vaikuttavista tekijöistä. Maatal. tiet. aikak. 36: 14-21.

(10) - 1964. Mustaherukan C-vitamiinipitoisuus. Kotitalous 28,5: 151-153.

(11) Joyce, A. E. 1959-60. Quality in soft fruit. Sci. Horticult. XIV: 116-125.

(12) LARSSON, G. 1959. Norrländska sortförsök med svarta vinbär 1944-1958. Stat. trädg.förs. Medd. 122: $1-30$.

(13) Otrosson, L. 1958. Growth and maturity of peas for canning and freezing. Skrifter från institutionen för växtodlingslära vid kungl. lantbrukshögskolan - växtodling-plant husbandry, 9. 112 pp. Uppsala.

(14) Ронјакаllıo, O. 1943. Päivän pituuden ja lämpötilan vaikutuksesta kasvien kehityksen nopeuteen ja sadon määrään. Maatalous 36: 138-143, 175-176.

(15) - - 1949. Suomen pitkän kesäpäivän kasvinviljelyllemme tarjoamista mahdollisuuksista. Valvoja n:o 2, pp. 65-72.

(16) - - 1951. Pohjolan kesäpäivän pituuden mahdollisuudesta korvata kasvukauden lyhyys. Luonnon Tutkija 55: 120-124.

(17) Robinson, W. B. \& Stotz, E. 1945. The indophenol-xylene extraction method for ascorbic acid and modifications for interfering substances. J. Biol. Chem. 160: 217-225.

(18) Suomen Maantieteellinen Seura (The Geographical Society of Finland). 1960. Suomen Kartasto (Atlas of Finland). Helsinki.

(19) Tressler, D. K. \& Joslyn, M. A. 1961. Fruit and vegetable juice processing technology. Westport, Connecticut. Pp. 453-457: Ascorbic acid in black currant fruits and juices, by V. L. S. Charley.

S E L O S T U S:

\section{MUSTAHERUKAN TÄRKEIMMISTÄ LAATUOMINAISUUKSISTA ERÄILLÄ KOTIMAASSA VILJELLYILLA LAJIKKEILLA}

I. Askorbiinihappo.

Taina KuUsi

Valtion teknillinen tutkimuslaitos, Elintarviketeollisuuslaboratorio, Otaniemi

Kotimaassa viljeltyjen mustaherukkalajikkeiden laatuominaisuuksien selvittämiseksi suoritettiin vertaileva tutkimus 12 lajikkeella. Näytteitä saatiin 6 eri paikkakunnalta, joista eteläisin oli Piikkiö ja pohjoisin Rovaniemi, kolmen vuoden aikana. Saatuja analyysituloksia verrattiin k.o. vuosien lämpösummiin, aurinkosummiin ja sademääriin.

Askorbiinihappo, jonka määrä on eräs tärkeimmistä laatuominaisuuksista, määritettiin hiukan muunnetulla Robinson \& Stotzin menetelmällä. Saatujen tulosten perusteella oli mahdollista verrata keskenään eri lajikkeita sekä tarkastella sääolosuhteiden ja paikkakunnan pohjoisuuden mahdollista vaikutusta. Askorbiinihapon määrän tiedetään olevan lajikkeesta riippuvainen. Niinpä todettiinkin lajikkeiden askorbiinihappomäärässä seuraava aleneva sarja: Boskoop, Roodknop, Westwick Choice, Wellington XXX, Gerby, Wellington X, Åström, Brödtorp, Goliath, Silvergieter, Janslunda ja Lepaan musta. Tässä sarjassa totaali askorbiinihapon määrä vaihteli rajoissa $250-127 \mathrm{mg} / 100 \mathrm{~g}$. Kullakin lajikkeella esiintyi kuitenkin melkoisia vaihteluja. 
Sääolosuhteista suurin vaikutus oli kesän lämpötilalla; yleensä alhainen lämpötila suurensi askorbiinihapon määrää. Brödtorp ja Lepaan musta muodostivat usein poikkeuksen. Aurinkoisuus vaikutti samaan suuntaan kuin lämpötila, mutta vaikutus oli vähäisempi; sademäärällä taas ei todettu selvää vaikutusta. Paikkakunnan pohjoisuuden vaikutusta näyttää jossakin määrin esiintyvän. Tämä vaikutus perustunee lähinnä siihen, että pohjoisuus alentaa lämpötilaa ja täten hidastuttaa kypsymistä, joka puolestaan suurentaa askorbiinihapon määrää.

Vertailu kirjallisuuteen osoittaa nyt saatujen arvojen pääpiirteissään vastaavan aikaisempia tuloksia. Esiintyvät erot johtunevat lähinnä määritysmenetelmästä tai lajikkeensisäisistä vaihteluista; myös kasvatuspaikan pohjoisuudella ja kypsyysasteella voi olla vaikutusta. 